\title{
Retrospective Evaluation of Frequency, Morbidities and Mortality of Low Birth Weight Infants
}

\author{
Kadir Ömer Çetin, ${ }^{1}$ Didem Arman, ${ }^{2}$ Serdar Cömert ${ }^{2}$
}

'Department of Pediatrics, University of Health Sciences İstanbul Training and Research Hospital, İstanbul, Turkey ${ }^{2}$ Department of Pediatrics, Division of Neonatology, University of Health

Sciences İstanbul Training and Research Hospital, İstanbul, Turkey

Submitted: 26.06 .2019 Accepted: 22.07.2019

Correspondence: Didem Arman, Sağlık Bilimleri Üniversitesi İstanbul Eğitim Araştırma Hastanesi, Yenidoğan Kliniği, İstanbul, Turkey E-mail:dr_didemcaktir@yahoo.com

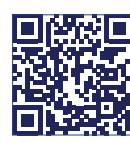

Keywords: Low birth weight; morbidity; neonate.

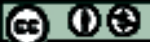

This work is licensed under a Creative Common Attribution-NonCommercial 4.0 International License.

\begin{abstract}
Objective: The aim of this study was to determine the frequency, morbidity, and mortality of low birth weight (LBW) infants born in a single hospital and to compare this group with infants of normal birth weight.

Methods: Infants born in our hospital between January I, 2013 and December 3I, 20I7 with a birth weight $<2500 \mathrm{~g}$ were included in the study group. Babies with a birth weight $>2500$ g were randomly selected as a control group. The demographic and clinical characteristics, neonatal intensive care unit (NICU) hospitalization, etiology, morbidity, presence of asphyxia, and mortality were recorded and statistically analyzed.
\end{abstract}

Results: In a 5-year period, the frequency of LBW infants ( $<2500 \mathrm{~g})$ was $8.72 \%(n=2120)$. Among LBW infants, there were more females than males $(p<0.00 \mathrm{I})$. The median first and fifth minute Apgar score in the study group was 7 and 8 , while it was 8 and 9 in the control group, which yielded a statistically significant difference between the groups $(p<0.00 \mathrm{I})$. Mothers younger than 20 years and over the age of 35 years were found to have a statistically significantly greater number of babies with LBW $(p=0.04 \mathrm{I}$ and $p=0.028)$. The mortality rate in LBW infants was determined to be 20 in 1000 live births. The rate of asphyxia observed among LBW infants and newborns with normal birth weight was found to be $0.6 \%$ and $0.28 \%$, respectively. It was observed that $66 \%$ of newborns with LBW required hospitalization in the NICU, compared with $16 \%$ of those with a normal birth weight. The leading etiologies for NICU admission among LBW infants were sepsis $(n=738,34.81 \%)$, respiratory distress syndrome (RDS) $(n=634,29.9 \%)$, and transient tachypnea of the newborn (TTN) $(n=489,23.99 \%)$. When compared with the control group, RDS, TTN, congenital pneumonia, sepsis, hyperbilirubinemia, hypoglycemia, polycythemia, and feeding intolerance were more frequent among the LBW group $(p<0.005)$. The leading morbidities among LBW infants were retinopathy of prematurity $(n=177,8.35 \%)$, anemia $(n=I \mid I, 5.24 \%)$, bronchopulmonary dysplasia $(n=49,2.38 \%)$, intraventricular hemorrhage $(n=32,1.51 \%)$, and necrotizing enterocolitis $(n=16,0.75 \%)$.

Conclusion: The frequency of low birth weight has varied over time but continues to be a concern. Since Apgar scores were lower and the rates of asphyxia, hospitalization, morbidity and mortality were all increased among LBW infants, antenatal follow-up of these high risk neonates is essential. Optimum resuscitation and medical care by an experienced NICU team after birth is invaluable.

\section{INTRODUCTION}

Low birth weight (LBW) infants are defined by the World Health Organization (WHO) as newborns with a birth weight under 2500 grams. Improved socioeconomic status, developments in modern medicine, innovations in the follow-up of high-risk pregnancy and current approaches in the treatment strategies of premature-low birth weight infants are increasing the number of low birth weight and premature infants. This increase in the number of babies born with low birth weight (LBW) is expected to increase the long-term morbidity associated with LBW.

Endocrinological diseases such as maternal metabolic syndrome and diabetes mellitus, arthritis, chronic heart disease, stroke, hypertension, malignancy, dementia, age, socioeconomic status, educational background, lack of prenatal diagnosis and treatment centers may increase the risk of LBW. ${ }^{[1]}$

LBW prevalence is higher in emerging countries. While the prevalence of LBW in developed countries is $5-7 \%$, it 
increases up to $19 \%$ in emerging countries. In a study conducted in Ethiopia, the prevalence of LBW was found as $17.1 \%$, while the prevalence of LBW in India was found as $19.3 \% .{ }^{[2,3]}$ In another study conducted in the United States in 1996, the prevalence of LBW was $7.7 \%$, but it was detected as $8.2 \%$ in $2009 .{ }^{[4]}$ In a meta-analysis of 44 studies published in Iran between 1999 and 2017, the prevalence of LBW infants in Iran was found to be $8 \% .{ }^{[5]}$ In a study conducted between 2004 and 2008 in Turkey, which included 19533 birth, LBW prevalence was determined to be $10.61 \%$. ${ }^{[6]}$

Low birth weight has proven to be associated with hypertension, diabetes mellitus and other metabolic diseases from childhood chronic diseases. ${ }^{[7]}$ Low birth weight is known to be one of the most important causes of perinatal mortality and morbidity. Multicenter studies have shown that neonates born with a birth weight between I 500 and 2500 grams have a 20 -fold higher risk of neonatal death than neonates with normal birth weight. ${ }^{[8,9]}$

The fact that LBW infants carry a higher mortality and morbidity risk than other babies makes this newborn group more considerable for community health. Since the prevalence of LBW newborns is a valuable parameter in terms of mother and child health monitoring in our country and in other countries, up-to-date evaluations in this field are important. In this study, we aimed to determine the incidence by years, morbidity and mortality rates of LBW infants born in our hospital between January I, 2013 and December 31, 2017.

\section{MATERIALS AND METHODS}

The study was designed retrospectively with medical records scanning of infants and their mothers, born between January I, 2013 and December 3I, 20I7. Of these babies, LBW newborns with a birth weight $<2500$ grams made up our study group. For each year, a control group of babies weighing more than 2500 grams was randomly selected per the number of cases in the study group. The study was initiated after the approval of the ethics committee of the Medical Research Ethics Committee of our hospital.

Maternal age, type of delivery, gestational age, sex, birth weight, height, head circumference, presence of stillbirth, APGAR score of $I^{\text {st }}$ and $5^{\text {th }}$ minutes, newborn intensive care unit hospitalization status, diagnosis if hospitalization is present, morbidities, asphyxia and mortality status were recorded of mothers and infants in the study group and control group from the scanned files. Maternal age was divided into three groups as $<18$ years, between $18-35$ years and $>35$ years. Infants with congenital anomalies incompatible with life, babies with insufficient file data and babies referred from external centers were not included in the study.

With file scans, 2120 cases that could be included in the study and 2120 control group babies were detected. Frequency and percentage values were calculated for categorical variables. Mean, standard deviation and median values were given for continuous variables. Normal distribution of continuous variables was tested by Kolmogorov-Smirnov test. Chi-squared test was performed for relationships between categorical variables. Where appropriate, categorical variables were evaluated by Fisher's exact test. In variables that do not meet the normal distribution assumption; Mann-Whitney $U$ test was used for comparison of two independent groups and Kruskall-Wallis $\mathrm{H}$ test was used for comparison of more than two groups. Bonferroni Corrected Dunn's multiple comparison test was performed in order to find the source of the significant difference in the comparisons which were found to be significant by Kruskal-Wallis $\mathrm{H}$ test. $\mathrm{P}<0.05$ was considered statistically significant. Analysis was performed with NCSS I I (Number Cruncher Statistical System, 2017 Statistical Software).

\section{RESULTS}

Between January I, 2013 and December 31, 2017, there were 4649, 5223, 5302, 4518 and 4608 births in our hospital, respectively. Among these deliveries, the number of live babies with a birth weight of $<2500$ grams was 2120 . By years, 457, 464, 454, 365 and 380 live low birth weight babies were detected (Table I). Table I shows the incidence of LBW infants by years.

Of the babies with LBW $(n=|| 5 \mid), 54.29 \%$ were female $(n=969)$ and $45.71 \%$ were male (Table 2). Of the newborns with normal birth weight $(n=1013), 47.78 \%$ were female $(n=\mid 107)$ and $52.22 \%$ were male. Female sex was found to be statistically higher among infants with LBW $(p<0.00$ I) (Table 3).

When the age of the mothers of LBW infants was examined, $75.28 \%$ were between the ages of $20-35(n=1596)$, $10.28 \%$ were under the age of $20(n=218)$, and $14.43 \%$ were older than the age of $35(n=306)$ (Table 2). It was found that $80.24 \%$ of the mothers of the babies with normal birth weight were between $20-35$ years of age $(n=1701), 8.44 \%$ of them were under 20 years of age $(n=179)$, and II.32\% of them were 35 years of age or older $(n=240)$. Compared to the control group, the rate of having a baby with LBW was found to be significantly higher among mothers under 20 years of age $(p=0.04 I)$. Likewise, the rate of having a baby with LBW was significantly higher among mothers over 35 years of age $(p=0.028)$.

Table I. Distribution of low birth weight babies born between 2013-2017

\begin{tabular}{ccc}
\hline Year & $\begin{array}{c}\text { Total birth numbers, } \\
\mathbf{n}(\%)\end{array}$ & $\begin{array}{c}\text { Number of LBW } \\
\text { infants (n) }\end{array}$ \\
\hline 2013 & $4649(9.83 \%)$ & 457 \\
2014 & $5223(8.88 \%)$ & 464 \\
2015 & $5302(8.56 \%)$ & 454 \\
2016 & $4518(8.08 \%)$ & 365 \\
2017 & $4608(8.25 \%)$ & 380 \\
\hline
\end{tabular}


Table 2. Demographic data of LBW infants

\begin{tabular}{|c|c|c|}
\hline & $\mathbf{n}$ & $\%$ \\
\hline \multicolumn{3}{|l|}{ Mother age, n (\%) } \\
\hline$<20$ years & 218 & 10.28 \\
\hline 20-34 years & 1596 & 75.28 \\
\hline$>34$ years & 306 & 14.43 \\
\hline \multicolumn{3}{|l|}{ Delivery type } \\
\hline NSD & 661 & 31.18 \\
\hline $\mathrm{C} / \mathrm{S}$ & 1459 & 68.82 \\
\hline \multicolumn{3}{|l|}{ Sex } \\
\hline Female & 1151 & 54.29 \\
\hline Male & 969 & 45.71 \\
\hline \multicolumn{3}{|l|}{ AGA/SGA } \\
\hline AGA & 1627 & 76.75 \\
\hline SGA & 493 & 23.25 \\
\hline Asphyxia & 14 & 0.66 \\
\hline Mortality & 41 & 1.93 \\
\hline Hospitalization to NICU & 1403 & 66.18 \\
\hline Morbidity & 219 & 10.33 \\
\hline Apgar It $^{\text {st }}$ minute (median) (min-max) & \multicolumn{2}{|c|}{$7.00(1-9)$} \\
\hline Apgar $5^{\text {th }}$ minute (median) (min-max) & \multicolumn{2}{|c|}{$8.00(4-10)$} \\
\hline
\end{tabular}

LBW: Low birth weight; NSD: Normal spontaneous delivery; C/S: Cesarean section; AGA: Appropriate for gestational age; SGA: Small for gestational age; NICU: Neonatal intensive care unit; Min: Minimum; Max: Maximum.

Table 3. Comparison of case and control groups by sex

\begin{tabular}{lcccccc}
\hline & \multicolumn{2}{c}{ Control } & & \multicolumn{2}{c}{ Case } & p \\
\cline { 2 - 3 } & $\mathbf{n}$ & $\%$ & & $\mathbf{n}$ & $\%$ & \\
\hline Sex & & & & & \\
Female & 1013 & 47.78 & & 1151 & 54.29 & $<0.001$ \\
Male & 1107 & 52.22 & & 969 & 45.71 & \\
\hline
\end{tabular}

Table 4. Comparison of case and control groups according to $I^{\text {st }}$ minute and $5^{\text {th }}$ minute Apgar scores

\begin{tabular}{lccc}
\hline & $\begin{array}{c}\text { Case } \\
\text { (Median) } \\
\text { (Min-Max) }\end{array}$ & $\begin{array}{c}\text { Control } \\
\text { (Median) } \\
\text { (Min-Max) }\end{array}$ & p \\
\hline $\mathrm{I}^{\text {st }}$ minute Apgar score & $7.00(2-9)$ & $8.00(6-9)$ & $<0.001$ \\
$5^{\text {th }}$ minute Apgar score & $8.00(4-10)$ & $9.00(7-10)$ & $<0.001$ \\
\hline
\end{tabular}

When the first minute Apgar scores were compared, a statistically significant difference was found between the control and case groups $(p<0.00 I)$ (Table 4$)$. The $I^{\text {st }}$ minute Apgar median value of the control group was higher than the case group. When the $5^{\text {th }}$ minute Apgar scores were examined, a statistically significant difference was found between the control and case groups $(p<0.001)$. The 5 th minute Apgar median value of the control group was higher than the case group.
Table 5. Comparison of LBW infants and control group in terms of NICU hospitalization diagnoses

\begin{tabular}{|c|c|c|c|c|c|}
\hline & \multicolumn{2}{|c|}{ LBW } & \multicolumn{2}{|c|}{ Control } & \multirow[t]{2}{*}{$\mathbf{p}$} \\
\hline & $\mathbf{n}$ & $\%$ & $\mathbf{n}$ & $\%$ & \\
\hline RDS & 634 & 29.91 & II & 0.52 & $<0.001^{*}$ \\
\hline TTN & 489 & 23.07 & 103 & 4.86 & $<0.001^{*}$ \\
\hline Congenital pneumonia & 99 & 4.67 & 36 & 1.70 & $<0.001$ \\
\hline Sepsis & 738 & 34.81 & 118 & 5.57 & $<0.001$ \\
\hline Hyperbilirubinemia & 349 & 16.46 & 86 & 4.06 & $<0.001$ \\
\hline Dehydration & 73 & 3.44 & 57 & 2.69 & 0.154 \\
\hline Hypoglycemia & 100 & 4.72 & 16 & 0.75 & $<0.001$ \\
\hline Polycythemia & 114 & 5.38 & 25 & 1.18 & $<0.001$ \\
\hline Malnutrition & 187 & 8.82 & 12 & 0.57 & $<0.001$ \\
\hline Pneumothorax & 7 & 0.33 & 1 & 0.05 & $0.039^{*}$ \\
\hline Other & 79 & 3.73 & 6 & 0.28 & $<0.001$ \\
\hline
\end{tabular}

LBW: Low birth weight; NICU: Neonatal intensive care unit; RDS: Respiratory distress syndrome; TTN: Transient tachypnea of the newborn. Chi Squared Test "Fisher's Exact Test.

Table 6. Comparison of mortality in infants with LBW and control groups

\begin{tabular}{lcclccc}
\hline Mortality & \multicolumn{2}{c}{ LBW } & & \multicolumn{2}{c}{ Control } & p \\
\cline { 2 - 3 } & $\mathbf{n}$ & $\%$ & & $\mathbf{n}$ & $\%$ & \\
\hline 2013 & 7 & 1.53 & & 0.047 & $<0.00 \mathrm{I}$ \\
2014 & 7 & $1.5 \mathrm{I}$ & & 0 & 0 & $<0.00 \mathrm{I}$ \\
2015 & 8 & 1.76 & & 0 & 0 & $<0.00 \mathrm{I}$ \\
2016 & 13 & 3.56 & & 0 & 0 & $<0.00 \mathrm{I}$ \\
2017 & 6 & 1.58 & & 0 & 0 & $<0.00 \mathrm{I}$ \\
Total & $4 \mathrm{I}$ & 1.93 & & $\mathrm{I}$ & 0.047 & $<0.00 \mathrm{I}$ \\
\hline
\end{tabular}

LBW: Low birth weight.

The diagnosis of hospitalization in neonatal intensive care unit (NICU) in LBW infants is given in Table 5 .

When the infants with LBW and normal birth weight who were hospitalized in the neonatal intensive care unit were compared, the rates of hospitalization with RDS, TTN, congenital pneumonia, sepsis, jaundice, hypoglycemia, polycythemia, malnutrition and other diagnoses were found to be significantly higher in the LBW infant group $(p<0.05)$ (Table 5). There was no significant difference between the two groups in terms hospitalization rate for dehydration diagnosis.

When LBW infants and control group were compared in terms of mortality, it was found that mortality was significantly higher in LBW infants $(p<0.001)$ (Table 6), and mortality did not show any statistically significant difference in the case group by years $(p=0.181)$.

When LBW infants admitted to NICU were examined for morbidities, ROP was found in 177 (8.35\%), anemia in II I (5.24\%), BPD in 49 (2.3I\%), IVH in 32 (I.5I\%) cases and NEC in $16(0.75 \%)$ (Table 7$)$. 
Table 7. Comparison of the LBW infants and control group in terms of morbidities

\begin{tabular}{lcccccc}
\hline Morbidity & \multicolumn{2}{c}{ LBW } & & \multicolumn{2}{c}{ Control } & p \\
\cline { 2 - 3 } & $\mathbf{n}$ & $\%$ & & $\mathbf{n}$ & $\%$ & \\
\hline ROP & 177 & 8.35 & & 0 & 0 & $<0.001$ \\
Anemia & 111 & 5.24 & & 0.05 & $<0.001$ \\
BPD & 49 & 2.31 & & 0 & $<0.001$ \\
IVH & 32 & 1.51 & & 1 & 0.05 & $<0.001$ \\
NEC & 16 & 0.75 & & 0 & 0 & $<0.001$ \\
Other & 12 & 0.57 & & 0 & 0 & $<0.001$ \\
\hline
\end{tabular}

LBW: Low birth weight; ROP: Retinopathy of prematurity; BPD: Bronchopulmonary dysplasia; IVH: Intraventricular hemorrhage; NEC: Necrotizing enterocolitis.

\section{DISCUSSION}

Factors belonging to the mother before conception, or fetal, maternal and placental factors during pregnancy may affect birth weight. Birth weight, which may be affected by different factors at different periods, is the major determinant of neonatal morbidity and mortality. ${ }^{[10]}$ In addition to the negative effects of low birth weight in the neonatal period, the fact that it may lead to some chronic health problems in adult life shows that this situation is an important public health problem. Low birth weight infants are defined as newborns weighing less than 2500 grams by WHO. Although the incidence and prevalence of LBW infants varies by country and region, according to WHO data, the current prevalence of LBW worldwide is reported to be $15.5 \%$. According to the 2016 data of the United States National Vital Statistics Report, the incidence of LBW is $8.17 \%$. $^{[1]}$ According to the data obtained in our study, the incidence of LBW infants over a five-year period is $8.72 \%$. In a study by Akin et al. ${ }^{[6]}$ from Turkey between 2004 and 2008, LBW frequency was found to be $10.61 \%$. In another study by Altuncu et al. ${ }^{[2]}$ from Turkey in 2006, LBW frequency was found to be $9.14 \%$. When compared with these results, the results of our study were consistent with the study of Altuncu et al., and were found to have lower numbers compared to the results of Akin et al. Although it has not been investigated in our study, it suggests that this may be due to the possible effects of various factors such as geographic location, nutrition and sociodemographic characteristics on fetal growth and birth weight.

In our study, it was found that $75.28 \%$ of the mothers of LBW babies were between 20-35 years old, $10.28 \%$ were under 20 years old and $14.43 \%$ were 35 years old and over. The rate of having a baby with LBW was statistically higher among mothers under the age of 20 and over 35 years of age $(p=0.041$ and $p=0.028)$. When our results were compared with the age of the mothers of LBW babies found in the study of Akin et al., it was observed that the maternal population under 20 years and over 35 years of age was higher in our study. The results of the study conducted by
Carolan et al. ${ }^{[13]}$ published in 2013 were consistent with our results that concluded the risk of low birth weight increases with increasing maternal age.

In a study conducted by Shin et al. ${ }^{[14]}$ in Korea in 2005, the delivery type of LBW infants was examined and no significant difference was found between normal and cesarean births. In our study, the rate of spontaneous vaginal delivery was $31.18 \%$ and cesarean delivery rate was $68.82 \%$ in the LBW infant group. Cesarean delivery rate was significantly higher when compared with control group. It was concluded that this situation may be related to the increased incidence of cesarean section due to various reasons such as fetal distress and birth trauma in low birth weight infants, thus increasing the cesarean rate. The higher rates of cesarean delivery than those of the control group was consistent with the studies of Akin and Altuncu et al. ${ }^{[6,12]}$

In our study, $54.29 \%$ of the newborns with LBW were female and $45.71 \%$ were male. Female sex was more frequent in babies with LBW $(p<0.001)$. This result was similar to the results of Akin et al. However, Altuncu et al. in their study found that male and female sex ratios were similar in LBW babies and reported that the sex of the baby did not affect birth weight.

Studies conducted in the United States in 2015 and in Africa in 2017 included the results showing lower APGAR scores in newborns with LBW. ${ }^{[15,16]}$ In our study, the mean APGAR scores of the $1^{\text {st }}$ and $5^{\text {th }}$ minutes were 7 and 8 in LBW infants group, while it was 8 and 9 in the control group, respectively. This indicates that the mean APGAR scores were found to be lower as the birth weight decreased, consistent with the literature.

In our study, AGA and SGA rates of newborns with LBW were found as $76.75 \%$ and $23.25 \%$, respectively. Our results were in line with the high percentages of AGA in the study of Li-Yi Tsai et al. ${ }^{[18]}$ in Taiwan in 2014 and Puneet Sharma et al. in USA in 2004. ${ }^{[17]}$

In a study conducted in England and Wales between 1993 and 2001 , the mortality rate in infants with LBW between 1500 and 2500 grams was found to be 14.5 per 1000 live births. ${ }^{[19]}$ In our study, the mortality rate in LBW infants was found to be 20 per 1000 live births. In a study published in the US in 2015, infant mortality rate in newborns with LBW was 8 in 1000 live births, and infant mortality rate in infants with LBW in 2013 was 6 per 1000 according to the data of the United States National Vital Statistics Report. [20] In another study published in 2000 in Bangladesh with infants of 28-36 weeks of gestational age, mortality was found as 20 per 1000 live births. ${ }^{[2]}$ Our study results seem to be consistent with the results of this study.

In the study of Chen et al.," ${ }^{[8]}$ the incidence of neonatal asphyxia was found to be $0.83 \%$ among infants with LBW and $0.11 \%$ in newborns with normal birth weight. In our study, the prevalence of asphyxia was found to be $0.6 \%$ in newborns with LBW and $0.28 \%$ in newborns with normal birth weight. The results were consistent with 
Chen et al's study. The high risk of asphyxia in infants with LBW should be taken into consideration, and resuscitation should be performed by an experienced team when necessary.

In our study, we found that newborns with LBW had conditions requiring hospitalization in the neonatal intensive care unit at a rate of $66 \%$ in the postnatal period. This rate was $16 \%$ in infants with normal birth weight, and the difference was significant. This suggests that the presence of LBW in newborn infants is a risk factor for admission to the neonatal intensive care unit in accordance with the literature. ${ }^{[8]}$ In a study published by Nigel Paneth et al. ${ }^{[22]}$ in 1982, the rate of hospitalization of infants with LBW in the neonatal intensive care unit was found as $82.1 \%$. Although the results of Paneth et al. were higher than our study, the results support intensive care stay rates to be higher in LBW infants compared to normal weighed infants.

Sepsis (34.81\%), RDS (29.9\%), TTN (23.99\%) were the first three diagnoses for LBW infants to be hospitalized in the neonatal intensive care unit, followed by hyperbilirubinemia $(16.46 \%)$, malnutrition $(8.82 \%)$, polycythemia (5.38\%), hypoglycemia (4.72\%), congenital pneumonia (4.67\%), dehydration (3.44\%) and pneumothorax $(0.33 \%)$. These results showed that the rate of admission to intensive care unit were higher in LBW infants compared to normal weighed group for all the diagnoses except for the diagnosis of dehydration. $29.9 \%$ of the newborns with LBW admitted to the neonatal intensive care unit had RDS diagnosis. In a study conducted in the United States between 2003 and 2007 with only VLBW babies, RDS rates reached up to $93 \% .{ }^{[23]}$ In another study conducted only with VLBW babies in the United States between 1995 and 1996, the RDS rate was found to be $50 \%{ }^{[24]}$ Compared to these results, we observed that our study results were significantly lower than the results found in the literature. However, we thought that this was related to the high incidence of RDS because other studies included not only LBW infants but also VLBW infants. The results support our study in terms of the increasing probability of RDS observation as the birth weight decreases.

The frequency of LBW varies according to years. Cesarean delivery is more common in newborns with LBW. Due to the low APGAR scores, asphyxia, the frequency of intensive care unit admission, higher morbidity and mortality rates in LBW infants, it is important that these babies are adequately monitored in the womb and that an effective resuscitation is performed during labor and followed by an experienced team in the NICU.

Ethics Committee Approval

Approved by the local ethics committee.

Informed Consent

Retrospective study.

Peer-review

Internally peer-reviewed.
Authorship Contributions

Concept: S.C.; Design: S.C., K.Ö.Ç.; Supervision: S.K., D.A.; Materials: K.Ö.Ç.; Data: K.Ö.Ç.; Analysis: D.A.; Literature search: D.A.; Writing: K.Ö.Ç, D.A.; Critical revision: S.C.

Conflict of Interest

None declared.

\section{REFERENCES}

1. Emanuel I, Kimpo C, Moceri V. The association of maternal growth and socio-economic measures with infant birthweight in four ethnic groups. Int J Epidemiol 2004;33:1236-42.[CrossRef]

2. Bharati P, Pal M, Bandyopadhyay M, Bhakta A, Chakraborty S, Bharati P. Prevalence and causes of low birth weight in India. Malays J Nutr 2011;17:301-13.

3. Zeleke BM, Zelalem M, Mohammed N. Incidence and correlates of low birth weight at a referral hospital in Northwest Ethiopia. Pan Afr Med J 2012;12:4.

4. Darling RD, Atav AS. Risk factors for low birth weight in New York state counties. Policy Polit Nurs Pract 2012;13:17-26. [CrossRef]

5. Ebadi F, Ghashghaee A, Bragazzi NL, Martini M, Sepehrian R, Ghaemmohamadi MS, et al. Low birth weight in Iran: Implications from a systematic review of the literature and meta-analysis in the period 1999-2017. Med J Islam Repub Iran 2018;32:13. [CrossRef]

6. Akin Y, Cömert S, Turan C, Unal O, Piçak A, Ger L, Telatar B. Increasing low birth weight rates: deliveries in a tertiary hospital in istanbul. Iran J Pediatr 2010;20:284-90.

7. Goldenberg RL, Culhane JF. Low birth weight in the United States. Am J Clin Nutr 2007;85:584S-90S. [CrossRef]

8. Chen Y, Li G, Ruan Y, Zou L, Wang X, Zhang W. An epidemiological survey on low birth weight infants in China and analysis of outcomes of full-term low birth weight infants. BMC Pregnancy Childbirth 2013;13:242. [CrossRef]

9. Organization: WHO. Make every Mother and Child Count. The Greatest Risks to Life are in its Beginning. The World Health Report Geneva: WHO 2005:79-81. Available at: https://www.who.int/ whr/2005/whr2005_en.pdf. Accessed 16 Sep 2019.

10. Zacharias N. Perinatal mortality. UpTo Date September 2010:1146.

11. Martin JA, Hamilton BE, Osterman MJK, Driscoll AK, Drake P. Births: Final Data for 2016. Natl Vital Stat Rep 2018;67:1-55.

12. Altuncu E, Kavuncuoğlu S, Gökmirza PÖ, Albayrak Z, Arduç A. Incidence and fetal risk factors in etiology of low birth weight in 5000 infant. Marmara Medical Journal 2006;19:46-51.

13. Carolan M. Maternal age $\geq 45$ years and maternal and perinatal outcomes: a review of the evidence. Midwifery 2013;29:479-89. [CrossRef]

14. Shin SM, Chang YP, Lee ES, Lee YA, Son DW, Kim MH, et al. Low birth weight,very low birth weight rates and gestational age-specific birth weight distribution of korean newborn infants. J Korean Med Sci 2005;20:182-7. [CrossRef]

15. Bartman T, Bapat R, Martin EM, Shepherd EG, Nelin LD, Reber KM. Apgar Score at 5 Minutes Is Associated with Mortality in Extremely Preterm Infants Even after Transfer to an All Referral NICU. Am J Perinatol 2015;32:1268-72. [CrossRef]

16. Gudayu TW. Proportion and factors associated with low fifth minute Apgar score among singleton newborn babies in Gondar University referral hospital; North West Ethiopia. Afr Health Sci 2017;17:1-6. [CrossRef]

17. Sharma P, McKay K, Rosenkrantz TS, Hussain N. Comparisons of mortality and pre-discharge respiratory outcomes in small-for-ges- 
tational-age and appropriate- for-gestational-age premature infants. BMC Pediatr 2004;4:9. [CrossRef]

18. Tsai LY, Chen YL, Tsou KI, Mu SC; Taiwan Premature Infant Developmental Collaborative Study Group. The impact of small-for-gestational-age on neonatal outcome among very-low-birth-weight infants. Pediatr Neonatol 2015;56:101-7. [CrossRef]

19. Watkins WJ, Kotecha SJ, Kotecha S. All-Cause Mortality of Low Birthweight Infants in Infancy, Childhood, and Adolescence: Population Study of England and Wales. PLoS Med 2016;13:e1002018.

20. Matthews TJ, MacDorman MF, Thoma ME. Infant Mortality Statistics From the 2013 Period Linked Birth/Infant Death Data Set. Natl Vital Stat Rep 2015;64:1-30.

21. Kusiako T, Ronsmans C, Van der Paal L. Perinatal mortality attribut- able to complications of childbirth in Matlab, Bangladesh. Bull World Health Organ 2000;78:621-7.

22. Paneth N, Kiely JL, Wallenstein S, Marcus M, Pakter J, Susser M. Newborn intensive care and neonatal mortality in low-birth-weight infants: a population study. N Engl J Med 1982;307:149-55. [CrossRef]

23. Stoll BJ, Hansen NI, Bell EF, Shankaran S, Laptook AR, Walsh $\mathrm{MC}$, et al. Neonatal outcomes of extremely preterm infants from the NICHD Neonatal Research Network. Pediatrics 2010;126:443-56.

24. Lemons JA, Bauer CR, Oh W, Korones SB, Papile LA, Stoll BJ, et al. Very low birth weight outcomes of the National Institute of Child health and human development neonatal research network, January 1995 through December 1996. NICHD Neonatal Research Network. Pediatrics 2001;107:E1. [CrossRef]

\section{Düşük Doğum Ağılıklı Bebeklerin Görülme Sıklığı ile Morbidite ve Mortalitelerinin Geriye Dönük Olarak Incelenmesi}

Amaç: Çalışmanın amacı hastanemizde doğan düşük doğum ağılıklı (DDA) bebeklerin görülme sıklığını, morbidite ve mortalitelerini saptamak ve normal doğum ağılıklı bebeklerle kıyaslamaktır.

Gereç ve Yöntem: Hastanemizde I Ocak 20।3-3I Aralık 2017 arasında doğmuş, doğum tartısı 2500 gram altındaki yenidoğanlar olgu grubunu oluştururken, doğum tartısı 2500 gram üzeri olan bebekler kontrol grubu olarak seçildi. Demografik ve klinik veriler ile yenidoğan yoğun bakım ünitesi yatış durumu, tanı, morbiditeler, asfiksi varlığı ve mortalite kaydedilerek kıyaslandı.

Bulgular: Beş yıllık sürede DDA bebek sayısı 2 I 20 idi. Düşük doğum ağılıklı bebek görülme sıklığı \%8.72 olarak saptandı. DDA’ı bebekler arasında kız cinsiyet istatistiksel olarak daha fazla görülmekteydi (\%54.29'u kız, \%45.7l'i erkek) ( $\mathrm{p}<0.00 \mathrm{I})$. İki grup arasında APGAR skoru açısından istatistiksel olarak anlamlı bir farklılık tespit edildi $(p<0.00 \mathrm{I})$. Yirmi yaş altındaki ve 35 yaş üzerindeki annnelerin DDA'lı bebek sahibi olma oranı istatistiksel olarak anlamlı yüksek bulundu ( $p=0.04 \mathrm{I}, \mathrm{p}=0.028)$. DDA bebeklerde mortalite oranı 1000 canlı doğumda 20 idi. Asfiksi görülme sıklığı, DDA'ılarda \%0.6, kontrol grubunda ise \%0.28 olarak saptandı. DDA'lı bebeklerin \%66'sında, normal doğum tartısına sahip bebeklerin ise \% I6'sında yenidoğan yoğun bakım ünitesine yatış gerekmekteydi. DDA'lı bebekler arasında ilk üç sıradaki yatış tanıları sepsis $(n=738, \% 34.81)$, respiratuvar distres sendromu (RDS) $(n=634, \% 29.9)$ ve yenidoğanın geçici taşipnesi (YDGT) ( $n=489, \% 23)$ idi. DDA'lı bebek grubunda RDS, YDGT, konjenital pnömoni, sepsis, sarılık, hipoglisemi, polisitemi, beslenme bozukluğu ve diğer tanılarla yatış oranının istatistiksel olarak anlamlı yüksek olduğu tespit edildi $(p<0.05)$. Yenidoğan yoğun bakım ünitesine yatan DDA'lı bebekler morbiditeler açısından incelendiğinde I77'sinde (\%8.35) prematüre retinopatisi (ROP), II I'inde (\%5.24) anemi, 49'unda (\%2.3I) bronkopulmoner displazi (BPD), 32 (\%।.5I) olguda intraventriküler kanama (IVK) ve 16'sında (\%0.75) nekrotizan enterokolit (NEK) saptandı.

Sonuç: DDA sıklığı yıllara göre değişkenlik göstermektedir. APGAR skorlarının düşük, asfiksi, yoğun bakıma yatış sıklı̆̆ı, morbidite ve mortalitenin daha yüksek olması nedeniyle DDA'lı bebeklerin anne karnında yeterli izlemi yapılmalı, doğum sırasında etkili bir canlandırma uygulanarak postnatal dönemde ise YYBÜ'de deneyimli bir ekip tarafından takipleri planlanmalıdır.

Anahtar Sözcükler: Düşük doğum tartısı; morbidite; yenidoğan. 